\title{
Transmission of multiple resistant Salmonella Concord from internationally adopted children to their adoptive families and social environment: proposition of guidelines
}

\author{
R. Vanhoof • P. Gillis • O. Stévart • C. Boland • \\ O. Vandenberg $\cdot$ F. Fux $\cdot$ J.-M. Collard $\cdot$ S. Bertrand
}

Received: 17 March 2011 / Accepted: 20 June 2011 / Published online: 10 July 2011

(C) The Author(s) 2011. This article is published with open access at Springerlink.com

\begin{abstract}
Since 2004, an increasing number of multidrugresistant Salmonella serovar Concord infections have been isolated in Belgium among children adopted from Ethiopia. The patients or their family were interviewed and the isolates were subtyped. Between 2004 and 2009, a total of 39 Salmonella Concord infections were isolated from patients. Thirty-four isolates presented a multidrug resistance includ-
\end{abstract}

Raymond Vanhoof, Philippe Gillis and Oriane Stevart contributed equally to this work

R. Vanhoof $\cdot$ C. Boland $\cdot$ F. Fux $\cdot$ J.-M. Collard $\cdot$ S. Bertrand $(\bowtie)$ National Reference Centre for Salmonella and Shigella, Bacterial Diseases Division, Communicable and infectious Diseases,

Scientific Institute of Public Health,

14 Wytsmanstreet,

1050 Brussels, Belgium

e-mail: sophie.bertrand@wiv-isp.be

O. Stévart

Département de Pédiatrie, Hôpital Universitaire des Enfants Reine Fabiola, Université Libre de Bruxelles,

Brussels, Belgium

P. Gillis

Dienst Kinder en jeugdgeneeskunde, Virga Jesseziekenhuis,

Hasselt, Belgium

O. Vandenberg

Infectious Diseases Epidemiological Unit,

Public Health School, Université Libre de Bruxelles,

Brussels, Belgium

O. Vandenberg

Department of Microbiology,

Saint-Pierre University Hospital and Jules Bordet Institute,

Brussels, Belgium

J.-M. Collard

CERMES, Centre de Recherche Médicale et Sanitaire,

Réseau International des Instituts Pasteur,

Niamey, Niger ing resistance to extended-spectrum cephalosporins. Thirtysix cases involved children and 30 of these were adopted from Ethiopia. One case was due to contact with an adopted child and for the other 5 cases no direct epidemiological link with Ethiopia could be found, although four isolates displayed the same patterns observed on the adoptees' isolates, strongly suggesting a phylogenetic relationship with the Ethiopian isolates. Our study confirmed the emergence in Europe of $S$. Concord isolates resistant to third-generation cephalosporin among Ethiopian adoptees. We have demonstrated that transmission (intra- and extra familial) can happen even if the frequency seems to be low. The presence and the transmission of such a multidrug-resistant Salmonella infection constitute a major concern, since such strains could jeopardize classical antibiotic therapy in patients at risk. This study provides useful information for parents adopting children and for their family practitioner.

\section{Introduction}

Approximately 40,000 children from 100 countries are adopted each year in western countries [1].

From 2004 to 2009, Belgian families adopted more than 2,000 children, mainly originating from China, Colombia, Russia, Philippines, India, Kazakhstan, and Ethiopia [2]. The number of international adoptees has increased steadily and the countries from which children are adopted change over time [3]. As a consequence, the epidemiology of diseases in this population of children shifts. International adoptees are usually under-immunized and are more exposed to infections because of crowded living conditions, malnutrition, lack of clean water and exposure to endemic diseases that are rare in western countries [4]. In order to control this evolution, various countries have issued new regulations. Nowadays, 
all children adopted internationally by US citizens must undergo a medical examination in their country of origin by a panel of physicians designated by the US Department of State followed by a medical examination within 2 weeks of their arrival in the United States [1]. In Belgium, the majority of adoptees undergo a medical examination by the Institute of Tropical Disease or by a physician with experience in adoption [2]. A study on the medical evaluation of internationally adopted children has shown that worldwide, more than $50 \%$ of newly arrived adopted children were medically undiagnosed. By using various diagnostic screening techniques, an infectious aetiological agent could be detected in $73 \%$ of the children with a medical evaluation [5]. Depending on the type of routine diagnosis (e.g. by direct examination, antigen detection and/or culture of the stool specimen), several studies identified an infectious etiological agent in approximately $50 \%$ of international adoptees, with parasites being the leading cause of abdominal complaints. The most common bacterial pathogens isolated on routine faecal culture include Salmonella spp. and Campylobacter jejuni $[3,6]$.

Salmonella enterica is a common cause of human gastroenteritis worldwide. Non-typhoid Salmonella infections commonly cause self-limiting gastroenteritis, but severe infections including bacteraemia, osteomyelitis and meningitis have also been reported [7, 8]. In general, antibiotic treatment is not required for Salmonella gastroenteritis unless it concerns invasive salmonellosis or affects immunocompromised patients [7, 9]. Although fluoroquinolones and extended-spectrum cephalosporins (ESC) are the drugs of choice to treat invasive Salmonella, resistance to these antibiotics is increasing worldwide [9].

Since 2003, a number of studies from Europe and the United States have shown an increased number of infections, with $S$. enterica serovar Concord among Ethiopian adoptees [10-12]. Isolates associated with patients of Ethiopian origin were all multi-resistant to antimicrobials including ESC.

In Belgium, similarly, an increasing number of infections caused by $S$. Concord has been observed among children adopted from Ethiopia. This trend paralleled the rise in the number of Ethiopian adoptees since 2004.

The objective of this study was:

1. To confirm the emergence of $S$. Concord isolates resistant to third-generation cephalosporins among Ethiopian adoptees in Belgium

2. To report the disease transmission from some of these children to their adoptive families and social contacts

3. To provide useful information for parents adopting children and for their family practitioner

4. To highlight the importance of prophylactic measures and appropriate hygiene, both at school and in the social environment of the child to prevent further dissemination

\section{Materials and methods}

Bacterial isolates

The Salmonella strains isolated from patients by peripheral clinical laboratories were transferred to the National Reference Centre for Salmonella and Shigella (NRCSS) for serotyping (approximately 3,000 to 6,000 strains/year). Serotyping of strains was carried out by slide agglutination with commercial antisera according to the KauffmannWhite scheme [13]. Data are registered in a database and strains are kept in collection. Data analysis allows following the epidemiological evolution of Salmonella isolates and when necessary to start a further characterization of isolates, as was the case with the $S$. Concord. An annual report on the activity of the NRCSS is available on http:// www.wiv-isp.be/bacterio/

Antimicrobial susceptibility testing

Susceptibility to 13 antibiotics was determined in strains isolated in Belgium using the disc diffusion method (Kirby-Bauer) following recommendations of the Clinical Laboratory Standards Institute (CLSI) [14]. Antibiotic disks were obtained from Biorad (Nazareth, Belgium). The antibiotics tested were: ampicillin (Amp), amoxicillin + clavulanic acid (Amx), cefotaxime (Ctx), chloramphenicol (Chl), tetracycline (Tet), nalidixic acid (Nal), ciprofloxacin (Cip), streptomycin (Str), kanamycin (Kan), gentamicin (Gen), sulfonamides (Sul), trimethoprim (Tmp), trimethoprim + sulfamethoxazole $(\mathrm{Sxt})$.

Pulsed-field gel electrophoresis

Pulsed-field gel electrophoresis (PFGE) analysis was performed according to the PulseNet Europe protocol (www.cdc.gov/pulsenet). Genomic DNA was digested with XbaI restriction enzymes (New-England Biolab, Leudsen, Netherlands). Braenderup H9812 digested with XbaI was used as a size marker.

PCR amplification of antimicrobial resistance genes and sequence analysis

Total DNA was extracted using the InstaGene matrix kit (Biorad, 9810 Nazareth, Belgium) according to the manufacturer's recommendations. The resistance genes bla $a_{\mathrm{TEM}}$, $b l a_{\mathrm{SHV}}, b a_{\mathrm{OXA}-1}$ group and $b l a_{\mathrm{CTX}-\mathrm{M}}$ were amplified by PCR and sequenced as described previously [15, 16]. To characterize the molecular basis of the quinolone resistancedetermining regions (QRDRs), the gyrA, gyrB and parC genes of isolates showing both reduced susceptibility to ciprofloxacin and resistance to $\mathrm{Nal}$, were subjected to 
PCR amplification and subsequent sequencing. PCR amplifications specific for $q n r A, B$ and $S$ genes were also performed $[15,17]$.

Epidemiological information

Medical records of patients with Salmonella Concord infections were retrospectively reviewed by linking microbiology test results with the respective medical records. The practitioners of the patients were interviewed to obtain information on the country of origin of the adoptees and their general health status. International travel, patient history and type of symptoms were also recorded, according to a standardized screening protocol $[5,6]$. In children presenting with diarrhoea, screening for parasites on three different samples with SAF preservative [18] was accompanied by culture for Salmonella, Shigella, Campylobacter species and Yersinia enterocolitica.

\section{Results}

Epidemiological data

Since 2004, the NRCSS observed a significant increase in the registration of $S$. Concord infections in Belgium $(p<$ 0.001; Fig. 1). Between 2004 and 2009, a total of 39 cases of laboratory-confirmed $S$. Concord infections were reported compared with only 8 cases during the period 1998-2003.

Out of the 39 cases, a total of 36 isolates were recovered from children, 30 of whom (83.4\%) were adopted from Ethiopia. The age of the children ranged from 0.1 year to 5.9 years with a mean age of $0.91 \pm 0.18$ year. Thirty-one children $(86.1 \%)$ were aged 1 year or less. In Belgium, the number of children adopted from Ethiopia increased significantly from $13.2 \%$ (62/470 international adoptions) in 2004 to $31.5 \%(142 / 451)$ in $2009(p<0.001)$.
Of the 39 isolates, 35 isolates were available for susceptibility testing because a lack of conservation in 2004 and 2005 (Table 1). Thirty-four isolates (97.1\%) were considered to be multi-drug resistant (MDR) to nine or more compounds, including third-generation cephalosporins. Only one isolate recovered from a Belgian child was susceptible to all antibiotics tested.

Five children of the 34 ESC-resistant cases were Belgian. One of them was infected through direct contact with an Ethiopian adoptee in his family in contrast to 3 other children in whom no direct link with Ethiopia could be found. There was no epidemiological information available for 1 case (Table 1).

Eight children were detected as carrying $S$. Concord for a period of 1.1 to 5.2 months. All adopted children with $S$. Concord carriage were asymptomatic or presented mild abdominal discomfort. The infants were examined as they were underweight. None of them complained of diarrhoea, abdominal complaints or nausea and/or vomiting. However, respiratory tract infections were present in 6 children, hepatitis in 2, scabies in 7, Giardia in 3, a skin infection in 2 and cytomegalovirus infection in 1 .

Out of the 39 cases, 3 adults were affected by the ESCresistant isolates; 1 was a Belgian mother of an Ethiopian adoptee, 1 had travelled to Ethiopia before becoming ill, and no direct link with Ethiopia could be found for an 87year-old person living in an care home.

Antimicrobial resistance phenotypes and genes and molecular typing

The antimicrobial resistance phenotypes of 35 tested isolates are shown in Table 1. The most prevalent multidrug resistance profile was Amp, Ctx, Str, Chl, Gen, Tet, Sul, Tmp, Sxt. Twenty percent $(n=7)$ of the isolates conferred a full resistance to nalidixic acid (Nal) with a reduced susceptibility to ciprofloxacin (MICs between 0.5 and $1 \mu \mathrm{g} / \mathrm{ml}$ ).

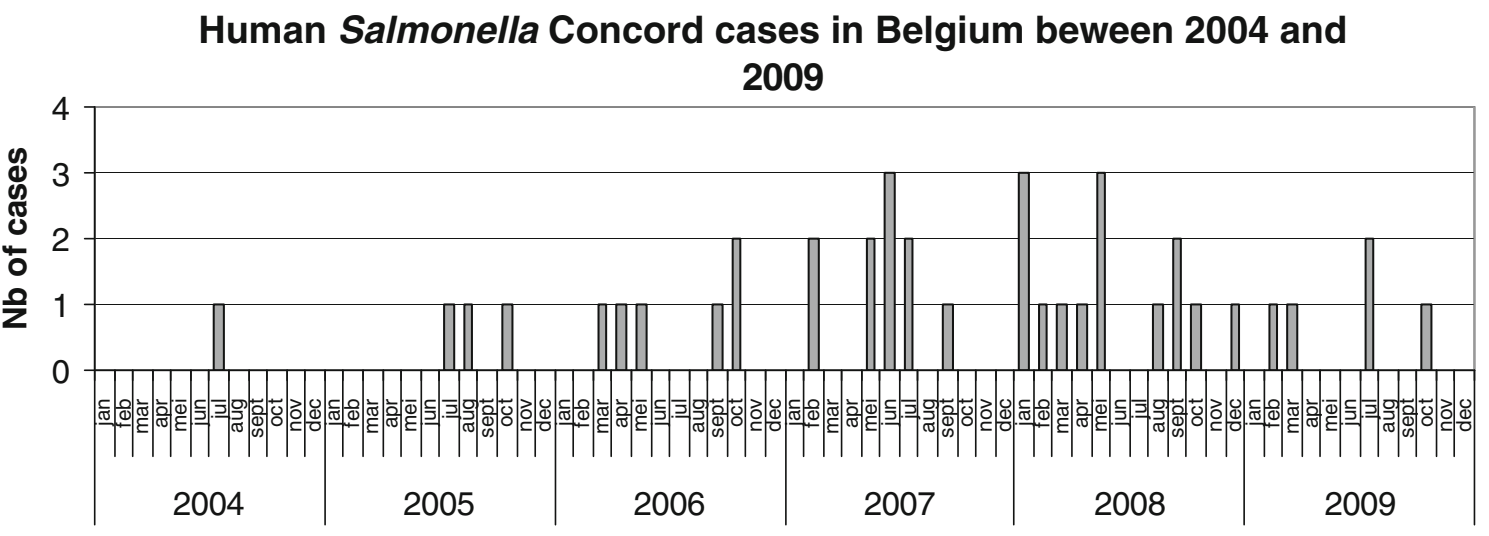

Fig. 1 Prevalence of Salmonella Concord in Belgium from 2004 to 2009 
Table 1 Characteristics of the S. enterica serotype Concord isolated since 2004

\begin{tabular}{|c|c|c|c|c|c|c|}
\hline Year & $\begin{array}{l}\text { Number of } \\
\text { isolates }\end{array}$ & Age $(n)$ & $\begin{array}{l}\text { Ethiopian adoption } \\
\text { status }(n)\end{array}$ & $\begin{array}{l}\text { Antimicrobial resistance phenotype } \\
(n)\end{array}$ & $\begin{array}{l}\text { b-Lactam resistance gene } \\
(n)\end{array}$ & $\begin{array}{l}\text { PFGE type } \\
(n)\end{array}$ \\
\hline 2004 & 1 & Child & Adoptees (1) & Not tested & Not tested & Not tested \\
\hline 2005 & 3 & Child & Adoptees (3) & Not tested & Not tested & Not tested \\
\hline \multirow[t]{6}{*}{2006} & \multirow[t]{6}{*}{6} & \multirow{5}{*}{$\begin{array}{l}\text { Children } \\
\text { (5) }\end{array}$} & \multirow[t]{2}{*}{ Adoptees (2) } & \multirow{2}{*}{$\begin{array}{l}\text { Amp, Ctx, Str, Chl, Gen, Tet, Sul, } \\
\text { Tmp, Sxt (2) }\end{array}$} & blaCTX-M-15 (1) & Xba-2 (1) \\
\hline & & & & & $\begin{array}{l}\text { blaCTX-M-15, blaTEM-1 } \\
\text { (1) }\end{array}$ & Xba-4 (1) \\
\hline & & & \multirow[t]{2}{*}{$\begin{array}{l}\text { No direct link } \\
\text { found (2) }\end{array}$} & \multirow[t]{2}{*}{$\begin{array}{l}\text { Amp, Ctx, Str, Chl, Gen, Tet, Sul, } \\
\text { Tmp, Sxt (2) }\end{array}$} & $\begin{array}{l}\text { blaCTX-M-15, blaSHV-12 } \\
\text { (1) }\end{array}$ & Xba-2 (1) \\
\hline & & & & & $\begin{array}{l}\text { blaCTX-M-15, blaSHV-12, } \\
\text { blaTEM-1 (1) }\end{array}$ & Xba-2 (1) \\
\hline & & & Unkonwn (1) & $\begin{array}{l}\text { Amp, Ctx, Nal, Str, Chl, Gen, Tet, } \\
\text { Sul, Tmp, Sxt (1) }\end{array}$ & $\begin{array}{l}\text { blaCTX-M-15, blaSHV-12 } \\
\text { (1) }\end{array}$ & Xba-1 (1) \\
\hline & & $\begin{array}{l}\text { Adults } \\
\text { (1) }\end{array}$ & Trip (1) & $\begin{array}{l}\text { Amp, Ctx, Str, Chl, Gen, Tet, Sul, } \\
\text { Tmp, Sxt (1) }\end{array}$ & $\begin{array}{l}\text { blaCTX-M-15, blaTEM-1 } \\
\text { (1) }\end{array}$ & Xba-2 (1) \\
\hline \multirow[t]{5}{*}{2007} & \multirow[t]{5}{*}{10} & \multirow[t]{4}{*}{$\begin{array}{l}\text { Children } \\
\text { (9) }\end{array}$} & \multirow[t]{4}{*}{ Adoptees (9) } & \multirow[t]{3}{*}{$\begin{array}{l}\text { Amp, Ctx, Str, Chl, Gen, Tet, Sul, } \\
\text { Tmp, Sxt (6) }\end{array}$} & blaCTX-M-15 (3) & $\begin{array}{l}\text { Xba-2 (2), } \\
\quad \text { Xba-5 (1) }\end{array}$ \\
\hline & & & & & $\begin{array}{l}\text { blaCTX-M-15, blaSHV-12 } \\
\text { (2) }\end{array}$ & Xba-2 (2) \\
\hline & & & & & $\begin{array}{l}\text { blaCTX-M-15, blaTEM-1 } \\
\text { (1) }\end{array}$ & Xba-2 (1) \\
\hline & & & & $\begin{array}{l}\text { Amp, Ctx, Nal, Str, Chl, Gen, Tet, } \\
\text { Sul, Tmp, Sxt (3) }\end{array}$ & $\begin{array}{l}\text { blaCTX-M-15, blaSHV-12 } \\
\text { (3) }\end{array}$ & Xba-2 (3) \\
\hline & & $\begin{array}{l}\text { Adults } \\
\text { (1) }\end{array}$ & $\begin{array}{l}\text { No direct link } \\
\text { found (1) }\end{array}$ & $\begin{array}{l}\text { Amp, Ctx, Nal, Str, Chl, Gen, Tet, } \\
\text { Sul, Tmp, Sxt } \\
\text { (1) }\end{array}$ & $\begin{array}{l}\text { blaCTX-M-15, blaSHV-12 } \\
\text { (1) }\end{array}$ & Xba-2 (1) \\
\hline \multirow[t]{11}{*}{2008} & \multirow[t]{11}{*}{14} & \multirow[t]{10}{*}{ Children } & \multirow[t]{7}{*}{ Adoptees (10) } & \multirow{3}{*}{$\begin{array}{l}\text { Amp, Ctx, Str, Chl, Gen, Sul, Tmp, } \\
\text { Sxt (3) }\end{array}$} & blaCTX-M-15 (1) & Xba-2 (1) \\
\hline & & & & & $\begin{array}{l}\text { blaCTX-M-15, blaTEM-1 } \\
\text { (1) }\end{array}$ & Xba-8 (1) \\
\hline & & & & & $\begin{array}{l}\text { blaCTX-M-15,blaSHV-12, } \\
\text { blaTEM-1 (1) }\end{array}$ & Xba-1(1) \\
\hline & & & & \multirow[t]{3}{*}{$\begin{array}{l}\text { Amp, Ctx, Str, Chl, Gen, Tet, Sul, } \\
\text { Tmp, Sxt (6) }\end{array}$} & blaCTX-M-15 (2); & $\begin{array}{l}\text { Xba-1(1), } \\
\text { Xba-2 (1) }\end{array}$ \\
\hline & & & & & $\begin{array}{l}\text { blaCTX-M-15, blaTEM-1 } \\
\text { (2) }\end{array}$ & $\begin{array}{l}\text { Xba-1(1), } \\
\quad \text { Xba-2 (1) }\end{array}$ \\
\hline & & & & & $\begin{array}{l}\text { blaCTX-M-15,blaSHV-12, } \\
\text { blaTEM-1 (2) }\end{array}$ & Xba-4 (2) \\
\hline & & & & $\begin{array}{l}\text { Amp, Ctx, Nal, Str, Chl, Gen, Tet, } \\
\text { Sul, Tmp, Sxt (1) }\end{array}$ & $\begin{array}{l}\text { blaCTX-M-15, blaTEM-1 } \\
\text { (1) }\end{array}$ & Xba-3 (1) \\
\hline & & & $\begin{array}{l}\text { Contact with } \\
\text { adoptees (1) }\end{array}$ & $\begin{array}{l}\text { Amp, Ctx, Str, Chl, Gen, Tet, Sul, } \\
\text { Tmp, Sxt (1) }\end{array}$ & $\begin{array}{l}\text { blaCTX-M-15,blaSHV-12, } \\
\text { blaTEM-1 (1) }\end{array}$ & Xba-3 (1) \\
\hline & & & \multirow{2}{*}{$\begin{array}{l}\text { No direct link } \\
\text { found (2) }\end{array}$} & susceptible (1) & - & Xba-6 (1) \\
\hline & & & & $\begin{array}{l}\text { Amp, Ctx, Str, Chl, Gen, Tet, Sul, } \\
\text { Tmp, Sxt (1) }\end{array}$ & blaCTX-M-15 (1) & Xba-4 (1) \\
\hline & & $\begin{array}{l}\text { Adult } \\
\text { (1) }\end{array}$ & $\begin{array}{l}\text { Contact with } \\
\text { adoptees (1) }\end{array}$ & $\begin{array}{l}\text { Amp, Ctx, Nal, Str, Chl, Gen, Tet, } \\
\text { Sul, Tmp, Sxt (1) }\end{array}$ & blaCTX-M-15 (1) & Xba-3 (1) \\
\hline \multirow[t]{3}{*}{2009} & \multirow[t]{3}{*}{5} & \multirow{3}{*}{$\begin{array}{l}\text { Children } \\
\text { (5) }\end{array}$} & \multirow[t]{3}{*}{ Adoptees (5) } & \multirow{3}{*}{$\begin{array}{l}\text { Amp, Ctx, Str, Chl, Gen, Tet, Sul, } \\
\text { Tmp, Sxt (5) }\end{array}$} & blaCTX-M-15 (3) & Xba-2, (3) \\
\hline & & & & & $\begin{array}{l}\text { blaCTX-M-15, blaTEM-1 } \\
\text { (1) }\end{array}$ & Xba-7 (1) \\
\hline & & & & & $\begin{array}{l}\text { blaCTX-M-15, blaTEM-1, } \\
\text { blaSHV-12 (1) }\end{array}$ & Xba-3 (1) \\
\hline
\end{tabular}

PFGE = pulsed-field gel electrophoresis; Amp = ampicillin; Amx = amoxicillin + clavulanic acid; Ctx = cefotaxime; Chl chloramphenicol; Tet = tetracycline; $\mathrm{Nal}=$ nalidixic acid; $\mathrm{Cip}=$ ciprofloxacin; $\mathrm{Str}=$ streptomycin; $\mathrm{Kan}=$ kanamycin; Gen $=$ gentamicin; Sul = sulfonamides; Tmp = trimethoprim; $\mathrm{Sxt}=$ trimethoprim + sulfamethoxazole

Mutations in the gyrA (Ser83Phe) and parC (Thr57Ser) were identified in three isolates with high level resistance to nalidixic acid (MICs of $>256 \mu \mathrm{g} / \mathrm{ml}$ ). Three out of the four isolates resistant to Nal with MICs between 96 and $128 \mu \mathrm{g} /$ 
$\mathrm{ml}$ contained the qnrA1 gene while the fourth one was positive for the $q n r B$ gene. Furthermore, all these isolates presented a mutation in the $\operatorname{parC}$ gene (Thr57Ser).

All of the 34 ESC-resistant isolates contained the

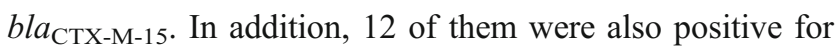
the penicillinase $b l a_{\mathrm{TEM}-1}$, whereas none was positive for the penicillinase $b l a_{\mathrm{OXA}-1}$. Concomitant to the $b l a_{\text {CTX-M-15, }}$, the $b l a_{\mathrm{SHV}-12}$ gene was also detected in 14 isolates. We did not observe a shift, over time, in the extended spectrum beta-lactamase (ESBL) distribution (i.e. $b l a_{\mathrm{CTX}-\mathrm{M}-15}$ replacing $\left.b l a_{\mathrm{SHV}-12}\right)$ as has been observed in other countries [12].

Clonal relationship of the 35 isolates was assessed by pulsefield gel electrophoresis of $\mathrm{X} b a$-I-digested chromosomal DNA (Fig. 2). Eight different PFGE profiles were obtained. No link between the PFGE profile and the $\beta$-lactam resistance gene type could be found. Among the dominant $X b a-2$ profile ( $n=$ 19), 8 isolates harboured the $b l a_{\mathrm{CTX}-\mathrm{M}-15}$ gene, 7 produced the $b l a_{\mathrm{CTX}-\mathrm{M}-15}$ in combination with $b l a_{\mathrm{SHV}-12}, 3$ produced $b l a_{\mathrm{CTX}-\mathrm{M}-15}$ and $b l a_{\mathrm{TEM}-1}$ and 1 isolate produced, $b l a_{\mathrm{CTX}-\mathrm{M}-15}$, $b l a_{\mathrm{SHV}-12}$ and $b l a_{\mathrm{TEM}-1}$ simultaneously.

Among the 5 cases for which no direct epidemiological link with Ethiopia could be found by interviews, 1 isolate was susceptible to all antibiotics tested and presented a completely different PFGE profile (Xba-6) (Fig. 2; Table 1). The four other isolates presented the common multidrug resistance profile Amp, Ctx, Str, Chl, Gen, Tet, Sul, Tmp, Sxt. In one isolate, this MDR profile was associated with $\mathrm{Nal}$ resistance. These isolates also displayed the common Xba-2 PFGE $(n=3)$ and Xba-4 PFGE profiles $(n=1)$, strongly suggesting a phylogenetic relationship with the Ethiopian isolates.

\section{Discussion}

Since 2004, Belgian families have adopted 655 children from Ethiopia. In 2009, they represented $31.5 \%$ of the internationally adopted children in Belgium. Ethiopia is one of the poorest countries in Africa with more than 4.5 million orphans and according to a recent study, intestinal parasites are commonly found in Ethiopian adoptees [19, 20]. Giardia lamblia was the most frequent pathogen isolated in this population, but because of an improper diagnosis procedure less is known about the other intestinal infectious diseases, including salmonellosis [20]. During the last decade, an increased incidence of Salmonella Concord infection among Ethiopian adoptees was noted in western countries [10-12]. This increasing incidence was also noted in our study. Indeed, 39 cases of $S$. Concord were notified in the period 2004-2009 against only 8 cases in the period 1998-2003. As in the other studies, a huge diversity of the PFGE patterns (8 patterns/35isolates) was observed among these isolates, indicating an endemic problem in Ethiopian orphanages. Most of the isolates showed multiple antibiotic resistance. In addition to ESBL production, $20 \%$ of the isolates displayed a resistance to nalidixic acid associated with a decreased susceptibility to ciprofloxacin. Fluoroquinolones are the drugs of choice for an invasive extra-intestinal infection in adults whereas ESC are preferentially used to treat salmonellosis in children. Resistance to ESC is a point of concern as the majority of the Salmonella Concord isolates was detected in children $<5$ years. Moreover, even a decreased susceptibility to fluoroquinolones has become a major problem in the treatment of patients infected by Salmonella isolates, as has been reported by Aarestrup et al. [21]. It is obvious that the problem is not limited to the introduction and dissemination of a possible exotic pathogen, but also comprises the introduction of antibiotic resistance determinants. Subsequently, these determinants can be transferred by horizontal genetic flux to the normal flora and other pathogenic bacteria. Eventually, this dissemination will jeopardize classical antibiotic treatments in patients at risk. This study confirmed the risk of contamination of the

Xbal PFGE

Xbal PFGE

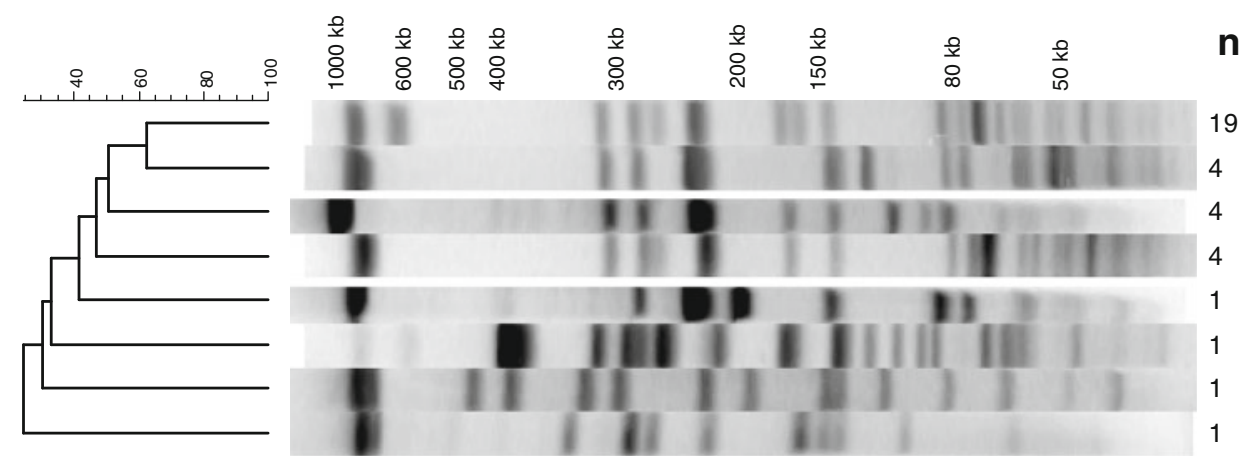

PFGE type

Xba-2

Xba-4

Xba-3

Xba-1

Xba-7

Xba-5

Xba-8

Xba-6

Fig. 2 Representative Xba-I pulsed field gel electrophoresis (PFGE) profiles of $S$. enterica serotype Concord isolates studied. A dendrogram was generated with Bionumerics software. The PFGE profile and number of isolates are indicated 
adoptee's entourage. Intra-familial transmission has been documented with variable transmission rates for different bacterial pathogens [22-24]. Parents of adoptees are at risk of both travel-related illnesses and infectious organisms carried by their adopted child. Other family members who did not travel may also be at risk through subsequent contact with the child [4]. We found this type of isolate in an elderly patient and in 4 children without any apparent link to Ethiopia. Even if the frequency of the transmission seems to be very low, this finding highlights the risk of a possible dissemination of these isolates in the general population. The extensive colonization time is another factor that may explain this dissemination of the Salmonella Concord. Our study has shown that adopted children can be carriers for a number of months. However, asymptomatic children who excrete an entero-pathogen usually do not need to be excluded from day care [25]. Nevertheless, it is important to recommend a systematic stool culture to screen for bacterial pathogens including Salmonella, even for asymptomatic adopted children. Families and close contacts of the respective children have to be informed of the risk of contamination and the preventive measures that should be taken.

A major problem concerns underestimation, both on the clinical and microbiological level, of the cases of microbial pathogens introduced by internationally adopted children. Indeed, in our study period we only received 30 isolates out of a total of 655 Ethiopian adoptees. In Belgium it is recommended that every child adopted from abroad undergoes a medical evaluation using simple screening tests following international recommendations $[5,6,17]$. The non-obligatory character of this test explains the fact that a lot of cases remain undiagnosed. Screening for ova and parasites is only requested for children with diarrhoeal symptoms using the triple-faeces test in which three stool samples, collected on 3 consecutive days, are examined according to a concentration technique and permanent staining. However, the screening should be systematic and could be enlarged to Salmonella, Shigella, Campylobacter spp., Yersinia enterocolitica and other infectious disease. It is clear that adoption can be a contributing factor in the spread of multi-drug resistance. Therefore, it is of utmost importance to perform a systematic screening for antimicrobial resistance, especially when adopted children come from countries known for a high prevalence of multiresistance. Parents should be stimulated to follow conscientiously the recommendations implemented to give the adopted children access to the best possible medical care.

Specific infection control strategies for households and community include meticulous hand washing and stringent sanitary procedures for toilet use and toilet training. These hygiene rules are especially important in diapered incontinent children. The risk of food contamination increased when people who care for diapered children also prepare or serve food as shown in some reports of Salmonella outbreaks in childcare programs [26]. Our study highlights the importance of prophylactic measures and appropriate hygiene, both at school and in the social environment of the child in order to prevent further dissemination. Competent authorities play a key role, not only in controlling the implementation of hygienic rules at the level of day care centres, but also in supplying practical information to the social environment of the future adoptee. Leaflets concerning the possible risk of infectious diseases, their transmission and impact on public health, and practical measures to contain this problem are more than welcome. Adequate information and well thoughtout practical protocols should be made available to the medical community involved in the follow-up of adopted children. Parents adopting children (especially from Ethiopia) and their general practitioners should be extensively informed of the possible infectious risks and the way to handle these risks.

Finally, we should realize that containment of the problem needs an international approach. International health care and educational organisations can support campaigns for vaccine-preventable diseases. Their financial support and logistic interventions will not only ameliorate the basic hygienic conditions in the orphanages, but will also have an impact on the sanitary situation in the countries of origin.

Acknowledgements We are very grateful to J. Griselain, F. Lamranni, M. Thirionet and G. Dupont for their technical help. We thank all clinicians and microbiologists for the submission of the isolates and the Health Inspectorate for their co-operation. We thank Rene Hendriksen for his critical revision of the manuscript. In Belgium, this work was financed in part by the Federal Public Health Service.

Open Access This article is distributed under the terms of the Creative Commons Attribution Noncommercial License which permits any noncommercial use, distribution, and reproduction in any medium, provided the original author(s) and source are credited.

\section{References}

1. Howard CR, John CC (2009) Centers for Disease Control and Prevention. Chapter 7: International travel with infants and children. International Adoptions. http:/wwwnc.cdc.gov/travel/yellowbook/ 2010/chapter-7/international-adoptions.aspx. Accessed July 27

2. Gillis P, Stevart O (2008) L'adoption n'est pas une maladie tropicale. J Pediatr Belg 10(1):25-27

3. Murray TS, Groth EM, Weitzman C, Cappello M (2005) Epidemiology and management of infectious diseases in international adoptees. Clin Microb Rev 18(3):510-520

4. Chen LH, Barnett ED, Wilson ME (2003) Preventing infectious diseases during and after international adoption. Ann Intern Med 139:371-378

5. Hostetter MK, Iverson S, Thomas W, McKenzie D, Dole K, Johnson DE (1991) Medical evaluation of international adopted children. N Eng J Med 325(7):479-485 
6. Miller LC (2005) International adoption: infectious diseases issues. Clin Infect Dis 40:286-293

7. Van Meervenne E, Botteldoorn N, Lokietek S et al (2009) Turtleassociated Salmonella septicaemia and meningitis in a 2-monthold baby. J Med Microbiol 58:1379-1381

8. Dhanoa A, Fatt QK (2009) Non-typhoidal Salmonella bacteraemia: epidemiology, clinical characteristics and its association with severe immunosuppression. Ann Clin Microbiol Antimicrob 8:15

9. Collard JM, Place S, Denis O et al (2007) Travel-acquired salmonellosis due to Salmonella Kentucky resistant to ciprofloxacin, ceftriaxone and co-trimoxazole and associated with treatment failure. J Antimicrob Chemother 60(1):190-192

10. Hendriksen RS, Mikoleit M, Kornschober C et al (2009) Emergence of multidrug-resistant Salmonella Concord infections in Europe and the United States in children adopted from Ethiopia, 2003-2007. Pediatr Infect Dis J 28(9):814-818

11. Hendriksen RS, Kjelso C, Torpdahl M, Ethelberg S, Molbak K, Aarestrup FM (2010) Upsurge of infections caused by Salmonella Concord among Ethiopian adoptees in Denmark, 2009. www. eurosurveillance.org. Accessed June 10

12. Fabre L, Delauné A, Espié E et al (2009) Chromosomal integration of the extended-spectrum $\beta$-lactamase gene $b l a_{\mathrm{ctx}-\mathrm{m}-15}$ in Salmonella enterica Serotpye Concord isolates from internationally adopted children. Antimicrob Agents Chemother 53(5):1808-1816

13. Grimont PAD, Weill F-X (2007) Antigenic formulae of the Salmonella serovars. World Health Organization, Institut Pasteur, Paris

14. National Committee for Clinical Laboratory Standards (2000) Performance standards for antimicrobial disk susceptibility tests, 7th edn. NCCLS document $n^{\circ}$. M2-A7. National Committee for Clinical Laboratory Standards, Wayne, pp 1-18

15. Bertrand S, Weill F-X, Cloeckaert A et al (2006) Clonal emergence of an extended spectrum $\beta$-lactamase-producing (CTX-M-2) Salmonella enterica serovar Virchow isolates with a reduced susceptibility to ciprofloxacin in poultry and humans in Belgium and France, 2000-2003. J Clin Microbiol 44:2897-2903

16. Toro CS, Farfan M, Contreras I, Flores O, Navarro N, Mora GC, Prado V (2005) Genetic analysis of antibiotic-resistance determinants in multidrug-resistant Shigella strains isolated from Chilean children. Epidemiol Infect 133:81-86
17. Cavaco LM, Frimodt-Moller N, Hasman H, Guardabassi L, Nielsen L, Aarestrup FM (2008) Prevalence of quinolone resistance mechanisms and associations to minimum inhibitory concentrations in quinolone-resistant Escherichia coli isolated from humans and swine in Denmark. Microb Drug Resist 14:163169

18. Vandenberg O, Van Laethem Y, Souayah H, Terfa Kutane W, van Gool T, Dediste A (2006) Improvement of routine diagnosis of intestinal parasites with multiple sampling and SAF-fixative in the Triple-Faeces-Test. Acta Gastroenterol Belg 19:361-366

19. Miller LC, Tseng B, Tirella LG, Chan W, Feig E (2008) Health of children adopted from Ethiopia. Matern Child Health 12:599-605

20. Beyene G, Nair S, Asrat D, Mengistu Y, Engers H, Wain J (2011) Multidrug resistant Salmonella Concord is a major cause of salmonellosis in children in Ethiopia. J Infect Dev Ctries 5(1):2333

21. Aarestrup FM, Wiuff C, Mølback K et al (2003) Is it time to change fluoroquinolone breakpoints for Salmonella spp.? Antimicrob Agents Chemother 47:827-829

22. Gustafson EB, Ringberg H, Johansson PJ et al (2007) MRSA in children from foreign countries adopted to Swedish families. Acta Paediatr 96:105-108

23. Ethelberg S, Olsen KE, Gerner-Smitdt P et al (2004) Household outbreaks among culture-confirmed cases of bacterial gastrointestinal disease. Am J Epidemiol 159:406-412

24. Tande D, Boisrame-Gastrin S, Munck MR, Hery-Arnaud G, Gouriou S, Jallot N, Nordmann P, Naas T (2010) Intrafamilial transmission of extended-spectrum-beta-lactamase-producing Escherichia coli and Salmonella enterica Babelsberg among the families of internationally adopted children. J Antimicrob Chemother 65(5):859-865

25. American Academy of Pediatrics (2009) Medical evaluation of internationally adopted children. In: Pickering L (ed) Red Book: report of the committee on Infectious Diseases, 28th edn. AAP Committee for Infectious Diseases, Elk Grove Village, IL

26. Yang HH, Gong J, Zhang J et al (2010) An outbreak of Salmonella Paratyphi A in a boarding school: a community-acquired enteric fever and carriage investigation. Epidemiol Infect 27:1-10 